\title{
Diagnostic significance of the synthesis of phenolic compounds and proline in the leaves of Schisandra chinensis and Actinidia arguta for the indication of the stress levels of plants under conditions of mixed plantings
}

\author{
(D) Tetyana Venediktova *, ㄴ) Natalia Zaimenko, 다№diia Skrypchenko
}

M.M. Gryshko National Botanical Garden, National Academy of Sciences of Ukraine, Tymiryazevska str. 1, 01014 Kyiv, Ukraine; * tatianaforest3@gmail.com

Received: 29.11 .2021 | Accepted: 20.12.2021 | Published online: 21.01.2022

\begin{abstract}
The peculiarities of the accumulation of polyphenolic compounds and free proline were investigated in the leaves of Actinidia arguta and Shisandra chinensis during their cultivation in vegetation containers with different ratios of the number of plants, namely $1: 1,2: 1,1: 2$. Monocultural (single-species) planting was used as a control. The content of free proline in plant leaves was carried out according to the method, which is based on the interaction of proline with a ninhydrin reagent, forming a pink-red color. The amount of polyphenolic compounds was determined by the Folin-Ciocalteu method. It was found that the ratio of plants grown together significantly affects the accumulation of primary and secondary metabolites in their leaves. Under conditions of mixed planting, more proline and phenolic substances are accumulated in plant leaves compared to monoculture. The maximum proline content, $19.44 \pm 0.91 \mathrm{mg} / \mathrm{g}$ of dry weight (DW), was observed in the leaves of $A$. arguta in the experiment combination with a prevailing number of schisandra plants at a ratio of $S$. chinensis and A. arguta plants of 2:1. In the same combination, the leaves of actinidia contained the highest amount of phenolic compounds ( $36.87 \pm 2.22 \mathrm{mg} / \mathrm{g} \mathrm{DW}$ ). The studied root exudates of the experimental plants had an allelopathic inhibitory effect on the test culture. The exudates caused $12.0 \%$ average decrease in root growth of $A$. arguta test objects, and $30.0 \%$ average decrease in root growth of $S$. chinensis test objects compared with the control. This allows us to conclude about the high activity of schisandra's allelochemicals, which negatively affect the development of actinidia plants. The optimal ratio of plants $A$. arguta and $S$. chinensis when grown together is $2: 1$, since a higher concentration of schisandra plants in a container more stress in actinidia plants, expressed as an increased accumulation of phenols and prolines in its leaves. The result of a comparative analysis of the amount of proline and phenolic compounds can be used to assess the mutual influence of plants in mixed plantings to optimize their growing conditions, which confirms the diagnostic significance of these metabolites for indicating the stress state of the studied plants.
\end{abstract}

Keywords: Actinidia arguta, Shisandra chinensis, phenolic compounds, proline, monocultures, mixed plantings, allelopathic activity

Authors' contributions: T. Venediktova was engaged in preparing and conducting the biochemical analyses, wrote the methodological part of the research, realized statistical processing of the experimental data, wrote the manuscript, and formulated conclusions. N. Zaimenko developed the research concept, interpreted the results. N. Skrypchenko wrote the manuscript, interpreted the results, and formulated conclusions.

Funding: The research has been carried out according to the science program of the Department of Fruit Plants Acclimatization of the M.M. Gryshko National Botanical Garden of the NAS of Ukraine "Theoretical bases of adaptive introduction for preservation of biological diversity of fruit plants of world flora".

Competing Interests: The authors declare no conflict of interest. 


\section{Introduction}

One of the directions for intensifying horticulture is the creation of highly productive plantations with greater technological and economic efficiency (Egorov, 2013). The main goal of intensive horticulture is to increase the productivity and quality of agricultural products and reduce material costs for agricultural production. A characteristic feature of a garden, as an agricultural phytocenosis, is its instability associated with the disruption of the trophic relationships of its components due to the intensive use of natural resources and technogenic factors (Popova, 2005). The garden's biotope is subjected to a long-term unilateral impact due to the use of monoculture and typical agricultural techniques (Kudasov, 1999). Gardens are monocultural (i.e., single-species) plantings, with decreased resistance and productivity of phytocoenoses. Long-term permanent cultivation of agricultural plants leads to a progressive deterioration of soil fertility and soil exhaustion. According to the Food and Agriculture Organization (FAO), soil exhaustion is responsible for the loss of $25 \%$ of the world crop yield (Zhuchenko, 2008). Numerous studies indicate that the symptoms of soil exhaustion are more pronounced in intensive gardens than in organic ones (Manici et al., 2003).

Diversifying the species composition of fruit plantations by increasing the biological diversity of garden phytocoenoses is possible due to the introduction of rare fruit plants into the culture, in particular the hardy kiwi (Actinidia arguta (Siebold et. Zucc.) Planch. ex Miq.) and Chinese magnolia vine (Shisandra chinensis (Turcz.) Baill.) valuable fruit, medicinal and ornamental plants. Fruits of A. arguta accumulate a high content of biologically active substances such as vitamins $\mathrm{C}, \mathrm{E}, \mathrm{K}$, polysaccharides, polyphenols, triterpenoids, and alkaloids, which have analgesic, antibacterial, antioxidant, antitumor, hypoglycemic, and other pharmacological effects (Sun et al., 2020). Fruits of S. chinensis is a source of biologically active compounds - vitamins $\mathrm{C}, \mathrm{E}$, and $\mathrm{P}$, saponins, flavonoids, organic acids, lignans, pectins, and aromatic substances, that have adaptogenic, tonic, immunostimulatory, regenerative, antitumor, and other effects (Szopa et al., 2016; Nowak et al., 2019). These plants are widely cultivated in industrial and farm horticulture of many countries. Significant introductory studies of A. arguta and $\mathrm{S}$. chinensis were carried out at the M.M. Gryshko National Botanical Garden (NBG) of the National Academy of Sciences of Ukraine (Skrypchenko \& Latocha, 2017). However, the development of scientific principles for their introduction into horticulture and the perfection of cultivation technology remains crucial.

According to the concept of green horticulture, the main principle for creating garden phytocoenoses should be to optimize their structure by creating multicomponent mixed plantings, that is, by moving from monoculture to polyculture (Moroz, 1990). Interest in "permanent agriculture" reflects growing attention to mixed plantings that are inherently more resilient than monocultures. They can protect and enrich soil ecosystems, allow plants to form mutually beneficial combinations, and create a favorable microclimate (Millner, 2016). With this in mind, studies of A. arguta and S. chinensis were realized to assess the possibility of co- $^{-}$ growth of these fruit vines in mixed plantings, as these plants are characterized by the same life form and similar agronomic cultivation requirements.

Since fruit plants not only absorb the essential mineral elements and organic compounds but also release various metabolites into the environment, the success of the integration of introduced species into the agrocoenoses depends on their allelopathic potential and living compatibility in mixed plantings (Osipova, 1997).

Physiological adaptation of plants to specific conditions is achieved through physiological and biochemical mechanisms. Elucidation of these mechanisms of plant adaptation to changing environmental conditions is of great theoretical and practical importance. Nowadays, it is one of the essential tasks of ecological plant physiology (Fedulov et al., 2015). The presence and accumulation of secondary metabolites reflect the adaptation strategy of plants created by natural selection in the course of evolution.

The effect of any abiotic or biotic stress factor on the plant organism provokes 
overproduction of reactive oxygen species (ROS) and upsets the balance between the level of ROS and the activity of the antioxidant defense system (Mittler, 2002; Foyer \& Noctor, 2000). An indicator of stress is the amount of proline, the content of which increases tens and hundreds of times under conditions of drought, salinity, high and low temperatures, and other damaging factors. Proline is the most abundant compound accumulated by plants in response to stress (Bassi \& Sharma, 1993; Ashraf \& Foolad, 2007; Verbruggen \& Hermans, 2008). It is an osmoprotector, a stabilizer of macromolecules and membranes, an additional source of energy and nitrogen, an antioxidant (Kuznetsov \& Shevyakova, 1999).

The dynamics of accumulation of phenolic compounds, which are important in the adaptation of the organism to environmental conditions, can also be used as a criterion for assessing the adaptive capacity of species (Zaprometov, 1993; Polyakova \& Yershova, 2000; Lattanzio, 2013). Changes in the content of phenolic compounds depending on the growing conditions provide the basis of the ecological stability of natural populations in the process of evolution and fit into the general mechanism of plant adaptation to habitat conditions (Polyakova, 1993). Phenolic compounds, or polyphenols, are among the most common secondary metabolites of vascular plants and are formed in all plants' cells and tissues (Alscher \& Hess, 2017). The structure of polyphenols is exceptionally diverse, as are the functions they perform. They are known to give color to flowers, fruits, and seeds and participate in plant growth and development regulation. They are chelators of heavy metals, regulate the expression of certain genes, and protect plants from stress (Bidel et al., 2010; Mierziak et al., 2014). Many flavonoids are allelochemicals involved in the formation of rhizobial symbiosis and mycorrhiza. The mechanism of action of allelochemical flavonoids is not fully understood; it is possible that they affect the auxin signaling of recipient plants and inhibit the growth of their cells, disrupt the synthesis of adenosine triphosphoric acid (ATP), induce the accumulation of ROS and, through calcium signaling, systemic root death (Mierziak et al., 2014). The accumulation level of phenolic compounds, to a certain extent, can serve as a criterion for the potential resistance of plants to stress (Zagoskina, 2005).

Laboratory bioanalysis is the first step to investigate the possible manifestation of allelopathy in the relationships between plants, plants and microorganisms, or plants and insects (Kondratyev, 2017). It is a necessary tool both for studying the allelopathic potential of plant or soil extracts and assessing the activity of extracts in the purification and identification of allelopathic compounds. The bioanalysis method supposes the germination of recipient plants' seeds in Petri dishes on filter paper, sand, soil, or agar. This is a fast method for a large number of biological repetitions. It can be used to identify potential allelopathic effects under controlled laboratory conditions, using the percentage of germinated seeds of recipient plants to measure the allelopathic activity of compounds (Gawronska et al., 2006).

This work aimed to study the accumulation peculiarities of proline and phenolic substances in the leaves of A. arguta and S. chinensis in vegetation experiments and model their co-growth to optimize their cultivation.

\section{Material and methods}

The research was carried out at the Department of acclimatization of fruit plants of the M.M. Gryshko National Botanical Garden, National Academy of Sciences of Ukraine. The experiments were carried out under controlled conditions. The temperature was maintained within $22 \pm 2{ }^{\circ} \mathrm{C}$, soil moisture $-60 \pm 5 \%$. Plants of A. arguta 'Sentyabrskaya' and S. chinensis 'Sadovy-1' were used as experimental objects. For each experiment combination, 12 twoyear-old vegetatively propagated plants were planted in the last decade of May in 12-liter containers filled with dark gray forest light loamy soil in a ratio of $1: 1,2: 1$, and $1: 2$; monocultural plantings of these plants served as control. The experiments were triplicated. Samples for biochemical studies were taken in mid-August. The coefficient of plant resistance was calculated as the ratio of the amount of proline or flavonoids in the leaves of plants of mixed plantings to the amount of the corresponding substances in plants in monoculture. 


\section{Determination of proline}

Determination of the content of free proline in plant leaves was carried out according to Bates et al. (1973). This method is based on the interaction of proline with a ninhydrin reagent, forming a pink-red color. The content of free proline was determined in a $2 \mathrm{~g}$ sample of plant material, which was ground in a mortar with quartz sand and $20 \mathrm{ml}$ of an aqueous solution of sulfosalicylic acid. After that, $2 \mathrm{ml}$ of the filtrate were mixed with $2 \mathrm{ml}$ of acidic ninhydrin and $2 \mathrm{ml}$ of glacial acetic acid in a test tube with a ground glass stopper. The mixture was kept for one hour in a boiling water bath and then cooled. Benzene $(4 \mathrm{ml})$ was added to the test tubes with the cooled mixture and vigorously shaken until the orange color passed into the organic solvent. The upper colored layer was poured into cuvettes $(20 \mathrm{~mm})$, and the color density of the solution was measured using a FEK-56M photoelectric colorimeter. Extinction was determined on a blue filter with a wavelength of $520 \mathrm{~nm}$. The amino acid concentration was calculated using a calibration curve built on standard proline solutions and expressed in $\mathrm{mg} / \mathrm{g}$ of dry weight (DW).

\section{Determination of polyphenolic compounds}

The amount of polyphenolic compounds was determined by the Folin-Ciocalteu method (Sibgatullina et al., 2011), which is widely used to analyze herbal preparations. The method is based on the Folin-Ciocalteu reagent, a mixture of phosphotungstic and phosphomolybdate heteropoly acids, which are reduced by phenolic compounds in an alkaline medium. During the reaction, polyphenolic compounds are oxidized by the action of the reagent, and a blue color appears due to the formation of a mixture of reduced tungstates and molybdates. Namely, $0.05 \mathrm{~g}$ of raw material samples were triturated with $1.5 \mathrm{~cm}^{3}$ of $96 \%$ ethanol; phenolic compounds were extracted for 45 minutes at $45^{\circ} \mathrm{C}$ with periodic stirring (every 15 minutes) and subsequent centrifugation for 2 minutes at a rotational speed of 16,000 rpm. After that, $0.075 \mathrm{~cm}^{3}$ of samples were taken from the obtained extract, added $0.075 \mathrm{~cm}^{3}$ of the Folin-Ciocalteu reagent, diluted five times, and stirred. After 3 minutes, $0.15 \mathrm{~cm}^{3}$ of $20 \%$ sodium carbonate solution and $1.2 \mathrm{~cm}^{3}$ of distilled water were added, covered with a lid, stirred, and left at room temperature. After one hour, the optical density of the formed tungsten blue was measured on a Specord-40 spectrophotometer at a wavelength of $725 \mathrm{~nm}$. The total content of phenolic compounds was expressed in mg-equivalents of gallic acid per $g$ of DW, the color intensity of which was proportional to the amount of phenolic compounds.

\section{Determination of allelopathic activity}

The allelopathic activity of the samples was determined according to the standard technique (Grodzinsky, 1991). To obtain root exudates, donor plants were grown in special funnels filled with quartz sand (Lobkov \& Konoshina, 2004). After 14 days of vegetation, samples of aqueous solutions of root exudates were taken. The resulting aqueous solutions containing root exudates were evaporated in a Heidolph Laborota 4002 rotary vacuum evaporator at $30^{\circ} \mathrm{C}$ and residual air pressure of 30 mbar. The final solution volume was obtained at the rate of $1 \mathrm{ml}$ from two and ten donor plants. The concentrated solutions were stored at below zero temperatures and used in further studies. An aqueous solution in a volume of $5 \mathrm{ml}$ was placed in Petri dishes, into which 50 pieces of watercress (Lepidium sativum L.) seeds were sown. The dishes were kept in the dark at room temperature for three days. After that, the length of L. sativum seedling roots was measured. The experiments were carried out in five replicates. Water served as a control.

\section{Statistical analysis}

The significance of differences between the combinations of the experiment was established by the dispersion method according to Fisher's test and the significance level of the null hypothesis. The obtained indicators, determined with a $95 \%$ confidence interval, are trustworthy due to the high reliability of the arithmetic mean values (the calculated Student's test value significantly exceeds the table values) and the error indicator of experience less than $5 \%$.

\section{Results and discussion}

As a result of the studies, it was found that in the leaves of A. arguta and S. chinensis grown in a mixed planting, a greater amount 
Table 1. Accumulation of proline in Actinidia arguta and Shisandra chinensis plants and their stress resistance coefficient in monocultures and mixed plantings.

\begin{tabular}{llllll}
\hline \multirow{2}{*}{$\mathrm{Nr}$} & Experiment combination & \multicolumn{3}{c}{ S. chinensis } & \multicolumn{3}{c}{ A. arguta } \\
\cline { 3 - 5 } & $\mathrm{mg} / \mathrm{g}$ DW & $\mathrm{k}$ & $\mathrm{mg} / \mathrm{g} \mathrm{DW}$ & $\mathrm{k}$ \\
\hline A & S. chinensis (control) & $6.98 \pm 0.36$ & & $9.64 \pm 0.41$ & \\
A & A. $\operatorname{arguta}($ control) & & & $13.57 \pm 1.9$ & 1.41 \\
B & S. chinensis (50\%) / A. arguta (50\%) & $19 \pm 0.95$ & 2.72 & $9.53 \pm 0.35$ & 0.99 \\
C & S. chinensis (33\%) / A. arguta (67\%) & $21.19 \pm 0.81$ & 3.04 & $19.44 \pm 0.91$ & 2.02 \\
D & S. chinensis (67\%) / A. arguta (33\%) & $12.4 \pm 0.64$ & 1.78 & 1.65 & \\
& LSD 0.95 & 1.88 & & & \\
\hline
\end{tabular}

Note. DW - dry weight; $\mathbf{k}$ - stress resistance coefficient; LSD - least significant difference.

of proline accumulates in comparison with the monoculture (Table 1).

The maximum amount of proline $(21.19 \pm 0.8$ $\mathrm{mg} / \mathrm{g}$ DW) was accumulated in S. chinensis leaves in the experiment combination with a prevailing ratio of actinidia plants in mixed planting (with $33 \%$ of S. chinensis and $67 \%$ of A. arguta). In this combination of mixed planting, the ratio of proline content in the leaves of schisandra to the corresponding value noted for the monoculture $(\mathrm{k})$ was 3.04 , which is the highest observed. The smallest $\mathrm{k}$ value (1.78) was noted in the experiment combination with $67 \%$ of S. chinensis and $33 \%$ A. arguta. This indicates that A. arguta plants have a repressing effect on $S$. chinensis plants in mixed plantings.

The amount of proline in A. arguta plants in the combination S. chinensis (33\%) / A. arguta (67\%) was $9.53 \pm 0.35 \mathrm{mg} / \mathrm{g}$ DW. A similar proline amount was registered for the control (monoculture) - 9.64 \pm 0.41 $\mathrm{mg} / \mathrm{g}$ DW. In all other combinations of the vegetation experiments with mixed plantings, both the amount of proline and the ratio of the value of proline in mixed plantings were much higher than the corresponding values in monoculture. The maximum content of proline $(19.44 \pm 0.91 \mathrm{mg} / \mathrm{g}$ DW) was observed in A. arguta in the experiment combination with the prevailing numbers of S. chinensis plants, with $67 \%$ of S. chinensis and $33 \%$ A. arguta, and with $\mathrm{k}=2.02$. The smallest coefficient $(\mathrm{k}=0.99)$ was obtained in the combination S. chinensis (33\%) / A. arguta (67\%). Thus, with an increase in the number of S. chinensis plants in a vegetation container, A. arguta plants experience more severe stress (Table 1).
A similar relationship was noted for S. chinensis with an increase of A. arguta plants.

Many plant species naturally accumulate proline as the main organic osmolytes when subjected to various abiotic stresses. Therefore, this compound, which is effectively involved in the mechanisms of ensuring plant resistance to stress, particularly plays an adaptive role in osmotic adaptation and protects subcellular structures in plants under stress conditions (Verbruggen \& Hermans, 2008; Chutia \& Borah, 2012). The response of fennel plants (Foeniculum vulgare Mill.) to environmental constraints was a marked increase in proline content in its leaves (Zali \& Ehsanzadeh, 2018).

The study of the features of the accumulation of phenols in the leaves of A. arguta and S. chinensis showed that their amount in S. chinensis leaves increases in mixed plantings with the prevailing number of A. arguta plants (Fig. 1).

The maximum accumulation of phenolic compounds $(36.87 \pm 2.22 \mathrm{mg} / \mathrm{g} \quad \mathrm{DW})$ in $\mathrm{S}$. chinensis leaves was observed in the combination S. chinensis (67\%) / A. arguta (33\%), where the ratio of phenols in the leaves of plants in mixed plantings to the amount of phenols in monoculture plants was the highest $(\mathrm{k}=2.09)$. The ratio was much lower $(\mathrm{k}=1.12)$ in the combinations of S. chinensis $(50 \%) /$ A. $\operatorname{arguta}(50 \%)$ and S. chinensis (33\%) / A. arguta (67\%). In leaves of A. arguta in monoculture, and in combinations $\mathrm{S}$. chinensis (33\%) / A. arguta (67\%), the phenol content differed insignificantly $(24.88 \pm 1.43 \mathrm{mg} / \mathrm{g}$ DW and $23.82 \pm 1.47 \mathrm{mg} / \mathrm{g}$ DW, respectively). In the experiment combinations $\mathrm{S}$. chinensis 


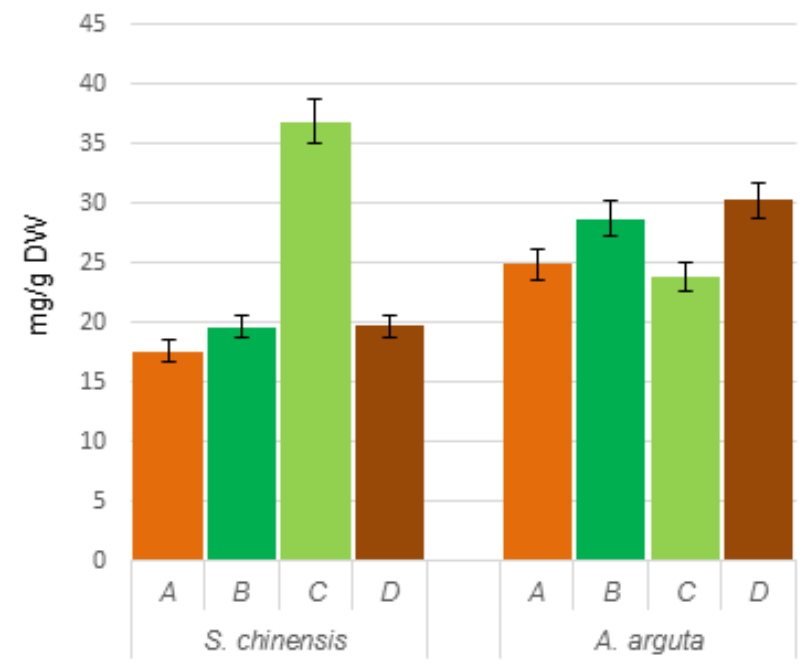

Figure 1. Accumulation of phenolic substances in plants of Actinidia arguta and Shisandra chinensis in monocultures and mixed plantings: A - A. arguta (control); B - S. chinensis (50\%) / A. arguta (50\%); C - S. chinensis (33\%) / A. arguta (67\%); D - S. chinensis (67\%) / A. arguta (33\%).

(50\%) / A. arguta (50\%) and S. chinensis (33\%) / A. arguta (67\%), an accumulation of a higher content of phenolic compounds in A. arguta leaves was observed. The highest coefficient of resistance to stress, $\mathrm{k}=1.22$, was recorded in the experiment combination with the prevailing number of $\mathrm{S}$. chinensis plants, namely S. chinensis (67\%) / A. arguta (33\%).

Thus, it was found that the content of secondary metabolites of phenolic nature in the leaves of plants changes depending on the ratio of experimental plants in the compositions of mixed plantings (Fig. 1). The research results revealed interspecific competition of plants in their co-cultivation, which leads to stress and can be manifested in relation to mineral nutrients, soil moisture, or be caused by root secretions of plants. The concentration and amount of biosynthesized phenolic compounds increase responding to stress factors. A similar reaction of plants is reported in several publications. In particular, the water stress increased the amount of the phenolic compounds in the vegetative organs of Hypericum brasiliense Choisy (Abreu \& Mazzafera, 2005). Similarly, waterdeficit stress increased the productivity of chlorogenic acid, catechin and epicatechin in hawthorn species (Kirakosyan et al., 2004).

To compare the allelopathic potential of the experimental plants, we studied the allelopathic activity of their root exudates by the biotesting method using the L. sativum as a test object (Fig. 2).

The allelopathic activity of the root exudates of A. arguta and S. chinensis plants was established. Their noticeable phytotoxic effect on the growth of roots of L. sativum seedlings was found. Compared with the control, the exudate of A. arguta suppressed L. sativum roots growth by $12.0 \%$ and S. chinensis - by $30.0 \%$. A decrease in the growth of L. sativum roots under the influence of aqueous solutions of root exudates indicates the presence of dissolved organic substances in the soil, which inhibit the development of test objects. As noted above, S. chinensis exhibits a stronger inhibitory effect on the test culture compared to A. arguta. These results confirm the previously obtained data that intravital secretions (leaf and root exudates) of S. chinensis and A. arguta contain allelopathically active compounds allelochemicals, which have a depressing effect on seed germination and growth of seedlings of various test objects (Osipova, 1997).

\section{Conclusions}

The results of the vegetation experiment indicate a pronounced interaction between A. arguta and S. chinensis crops during joint growth. The percentage of plants in model experiments significantly affects the accumulation of primary and secondary metabolites in leaves.

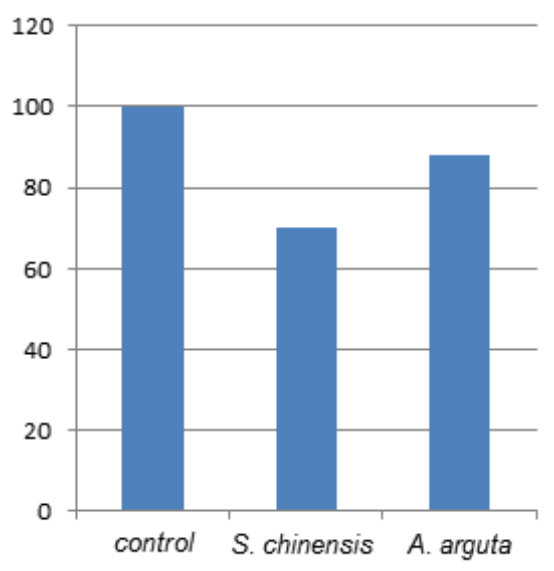

Figure 2. Allelopathic activity of root secretions of Actinidia arguta and Shisandra chinensis (bioassay - root growth of Lepidum sativum), percentage to control. 
The result of a comparative analysis of the amount of proline and phenolic compounds can be used to assess the mutual influence of plants in mixed plantings to optimize their growing conditions, which confirms the diagnostic significance of these metabolites for indicating the stress state of the studied plants.

The inhibitory effect of S. chinensis and A. arguta root secretions on L. sativum indicates their allelopathic activity, more pronounced in S. chinensis.

Based on our results, it is concluded that monoculture cultivation is the most optimal for both studied species. However, for the cogrowth of A. arguta and S. chinensis, planting in the ratio of $2: 1$ is the best.

\section{References}

Abreu, I., \& Mazzafera, P. (2005). Effect of water and temperature stress on the content of active constituents of Hypericum brasiliense Choisy. Plant Physiology and Biochemistry, 43(3): 241-248. https://doi.org/10.1016/j.plaphy.2005.01.020

Alscher, R., \& Hess, J. (2017). Antioxidants in higher plants. CRC press.

Ashraf, M., \& Foolad, M. R. (2007). Roles of glycine betaine and proline in improving plant abiotic stress resistance. Environmental and Experimental Botany, 59(2), 206-216. https://doi.org/10.1016/j. envexpbot.2005.12.006

Bassi, R., \& Sharma, S. S. (1993). Proline accumulation in wheat seedlings exposed to zinc and copper. Phytochemistry, 33(6), 1339-1342. https://doi.org/10.1016/0031-9422(93)85086-7

Bates, L. S., Waldren, R. P., \& Teare, I. D. (1973). Rapid determination of free proline for waterstress studies. Plant and Soil, 39, 205-207. https:// doi.org/10.1007/BF00018060

Bidel, L. P. R., Coumans, M., Baissac, Y., Doumas, P., \& Jay-Allemand, C. (2010). Biological activity of phenolics in plant cells. In C. Santos-Buelga, M. T. Escribano-Bailon \& V. Lattanzio (Eds), Recent advances in polyphenol research. Vol. 2 (pp. 163-205). Wiley-Blackwell. https://doi. org/10.1002/9781444323375.ch6

Chutia, J., \& Borah, S. (2012). Water stress effects on leaf growth and chlorophyll content but not the grain yield in traditional rice (Oryza sativa Linn.) genotypes of Assam, India. II. Protein and proline status in seedlings under PEG induced water stress. American Journal of Plant Sciences, 3(7), http://doi.org/10.4236/ajps.2012.37115
Egorov, E. (2013). Ecological-economical efficiency of the pomiculture intensification. Nauchnye trudy GNU SKZNIISIV, 2, 7-21. (In Russian)

Fedulov, Y. P., Kotlyarov, V. V., \& Dotsenko, K. A. (2015). Resistance of plants against adverse environmental factors. KubGAU. (In Russian)

Foyer, C. H., \& Noctor, G. (2000). Oxygen processing in photosynthesis: regulation and signaling. New Phytologist, 146(3), 359-388. https://doi. org/10.1046/j.1469-8137.2000.00667.x

Gawronska, H., Ciarka, D. \& Gawronski, S. (2006). Genetic diversity in crop allelopathy. In H. Østergård \& L. Fontaine (Eds), Cereal crop diversity: implications for production and products (pp. 92-94). ITAB.

Grodzinsky, A. (1991). Plant allelopaty and soil exhaustion. Naukova Dumka. (In Russian)

Kirakosyan, A., Kaufman, P., Warber, S., Zick, S., Aaronson, K., Bolling, S., \& Chul Chang, S. (2004). Applied environmental stresses to enhance the levels of polyphenolics in leaves of hawthorn plants. Phisiologia Plantarum, 121(2), 182-187. https://doi.org/10.1111/j.13993054.2004.00332.x

Kondratyev, M. (2017). Effect of root extrudes of culture plants on weeds growth. Requirements to the experimental methods. Nauchnaya Zhizn, 9, 14-21. (In Russian)

Kudasov, Y. (1999). Toward the question of gardening ecology. Plant physiology - basis of rational land use. Orlovsk Chapter of Plant Physiologists of the RAS. (In Russian)

Kuznetsov, V., \& Shevyakova, N. (1999). Proline during the stress: biological role, metabolism, regulation. Fiziologiya Rasteniy, 2, 321-336. (In Russian)

Lattanzio, V. (2013). Phenolic compounds: Introduction. In K. Ramawat \& J. M. Mérillon (Eds), Natural products (pp. 1543-1580). Springer. https://doi.org/10.1007/978-3-642-22144-6_57

Lobkov, V., \& Konoshina, S. (2004). Allelopathic properties of the soil as a fertility factor. Selskokhozyaystvennaya Biologiya, 3, 67-71. (In Russian)

Manici, L. M., Ciavatta, C., Kelderer, M., \& Erschbaumer, G. (2003). Replant problems in South Tyrol: role of fungal pathogens and microbial population in conventional and organic apple orchards. Plant and Soil, 256(2), 315-324. http://www.jstor.org/stable/24124252

Mierziak, J., Kostyn, K., \& Kulma, A. (2014). Flavonoids as important molecules of plant interactions with the environment. Molecules, 19(10), 16240-16265. https://doi.org/10.3390/ molecules191016240 
Millner, N. (2016). "The right to food is nature too": foodjustice and everydayenvironmental expertise in the Salvadoran permaculture movement. Local Environment, 22(6), 764-783 https://doi.org/10.10 80/13549839.2016.1272560

Mittler, R. (2002). Oxidative stress, antioxidants and stress tolerance. Trends in Plant Science, 7(9), 405-410. https://doi.org/10.1016/s13601385(02)02312-9

Moroz, P. (1990). Allelophaty in the fruit gardens. Naukova Dumka. (In Russian)

Nowak, A., Zakłos-Szyda, M., Błasiak, J., Nowak, A., Zhang, Z., \& Zhang, B. (2019). Potential of Schisandra chinensis (Turcz.) Baill. in human health and nutrition: a review of current knowledge and therapeutic perspectives. Nutrients, 11(2), Article 333. https://doi.org/10.3390/nu11020333

Osipova, I. (1997). Allelophatic tolerance of some fruit plants. Voprosy Bioindikatsii i Ekologii, 2, 9197. (In Russian)

Polyakova, L. (1993). Flavonoids in natural and introduction populations of the Siberia Fabaceae representatives [PhD thesis abstract, CSBG SC RAS]. (In Russian)

Polyakova, L. V., \& Yershova E. A. (2000). Variability of phenolic compounds in some herbaceous and woody plants from interpopulational to infraindividual (endogenic) level. Khimiya Rastitelnogo Syriya, 1, 121-129. (In Russian)

Popova, V. (2005). Agroecological aspects of productive garden ecosystems formation. SKZNIISiV. (In Russian)

Sibgatullina, G., Haertdinova, L., \& Gumerova, E. (2011). Methods of the redox-status determination in the cultivated plant cells. Kazan Federal University. (In Russian)
Skrypchenko, N., \& Latocha P. (2017). The genesis and current state of Actinidia collection in M.M. Gryshko National botanical garden in Ukraine. Polish Journal of Natural Sciences, 32(3), 513-525.

Sun, H., Bi, Y., Shi, D., Zhu, X., Li, L., Zaimenko, N., Skrypchenko, N., \& Liu, D. (2020). Research progress on fruit processing and storage preservation of Actinidia arguta. Food and Fermentation Industries, 46(11), 315-320. https:// doi.org/10.13995/j.cnki.11-1802/ts.023715

Szopa, A., Ekiert, R., \& Ekiert, H. (2016). Current knowledge of Schisandra chinensis (Turcz.) Baill. (Chinese magnolia vine) as a medicinal plant species: a review on the bioactive components, pharmacological properties, analytical and biotechnological studies. Phytochemistry Reviews, 16, 195-218. https://doi.org/10.1007/s11101016-9470-4

Verbruggen, N., \& Hermans, C. (2008). Proline accumulation in plants: a revie. Amino Acids, 35, 753759. https://doi.org/10.1007/s00726-008-0061-6

Zagoskina, N. (2005). Ability of different wheat cultivars to produce the phenolic compounds. Prikladnaya Biokhimiya i Mikrobiologiya, 41, 113116. (In Russian)

Zali, A., \& Ehsanzadeh, P. (2018). Exogenous proline improves osmoregulation, physiological functions, essential oil, and seed yield of fennel. Industrial Crops and Products, 111, 133-140. https://doi.org/10.1016/j.indcrop.2017.10.020

Zaprometov, M. (1993). Phenolic compounds: distribution, metabolism, and functions in plants. Nauka. (In Russian)

Zhuchenko, A. (2008). Adaptive plant cultivation (ecogenetic principles). Theory and practice. Agrorus. (In Russian)

\section{Діагностичне значення синтезу фенольних сполук і проліну в листках Schisandra chinensis та Actinidia arguta для індикації рівня стресу рослин в умовах змішаних насаджень}

Тетяна Венедиктова *, Наталія Заіменко, Надія Скрипченко

Національний ботанічний сад імені М.М. Гришка НАН України, вул. Тимірязєвська, 1, Київ, 01014, Україна; * tatianaforest3@gmail.com

Досліджено особливості накопичення поліфенольних сполук та вільного проліну в листках Actinidia arguta та Shisandra chinensis при їх вирощуванні в вегетаційних дослідах з різним співвідношенням кількості рослин в контейнерах, а саме $1: 1,2: 1,1: 2$. В якості контролю використовували одновидові посадки рослин. Вміст вільного проліну в листках рослин здійснювали за методикою, яка заснована на взаємодії проліну з реактивом нінгідрину, утворюючи рожево-червоне забарвлення. Кількість поліфенольних сполук визначали методом Фоліна-Чіокальтеу. Встановлено, що співвідношення рослин в контейнерах істотно впливає на накопичення первинних і вторинних метаболітів у їх 
листках. За умов змішаної посадки в листках рослин накопичувалося більше проліну та фенольних речовин порівняно з монокультурою. Максимальний вміст проліну 19,44 0,91 мг/г сухої маси (CM) спостерігався в листках A. arguta у варіанті з переважаючою кількістю рослин лимонника при співвідношенні рослин S. chinensis і A. arguta 2:1. У цьому ж варіанті найбільша кількість фенольних сполук (36,87 $\pm 2,22$ мг/г СM) була у листках актинідії. Досліджувані кореневі ексудати S. chinensis i A. arguta мали інгібуючу алелопатичну дію на тест-культуру. Ексудати A. arguta викликали середн зниження росту коренів тест-об'єктів на 12,0\%, a S. chinensis - на 30,0\% порівняно з контролем. Це дозволяє зробити висновок про високу активність алелохімікатів лимонника, які негативно впливають на ріст рослин актинідії. Оптимальне співвідношення рослин A. arguta i S. chinensis при спільному вирощуванні становить 2 : 1, оскільки вища концентрація рослин лимонника в контейнері посилює стрес у рослин актинідії, що виражається в підвищеному накопиченні фенолів і проліну в ії листках. Результат порівняльного аналізу кількості проліну та фенольних сполук може бути використаний для оцінки взаємного впливу рослин у змішаних насадженнях з метою оптимізації умов їх вирощування, що підтверджує діагностичну значущість цих метаболітів для індикації стресового стану рослин.

Ключові слова: Actinidia arguta, Shisandra chinensis, фенольні сполуки, пролін, монокультура, змішані насадження, алелопатична активність 